\title{
REFORMING THE REMEDY: GETTING THE RIGHT REMEDIAL STRUCTURE TO Protect Personal Privacy
}

\begin{abstract}
Nicholas Petrie*
Politicians, journalists and academics have exhausted many hours over the last decade debating the question of whether Australia should have a statutory cause of action for invasion of personal privacy. In the midst of this ongoing debate, a simple question has often been overlooked: what remedies should be available to a person whose privacy been breached? In posing and answering that question, it is argued that a wide range of remedies for intrusions of personal privacy should be available to the courts. Perhaps most controversially, the author asserts that exemplary damages, which aim to punish defendants and deter future breaches of the law, should be available for the most heinous breaches of personal privacy.
\end{abstract}

\section{INTRODUCTION}

Much has been written on the need or otherwise to introduce a statutory cause of action for invasion of personal privacy in Australia. ${ }^{1}$ Less attention has been given to the appropriate remedies that should accompany such a cause of

\footnotetext{
${ }^{*} \mathrm{BA} / \mathrm{LLB}(\mathrm{Hons})$ (University of Melbourne), Solicitor of the Supreme Court of Victoria.

${ }^{1}$ Australian Broadcasting Corporation v Lenah Game Meats Pty Ltd (2001) 208 CLR 199, 225-6 (Gleeson CJ), 248-58 (Gummow and Hayne JJ); 277 (Kirby J), 320-30 (Callinan J) ('Lenah Game Meats'); Megan Richardson, 'Whither Breach of Confidence: A Right of Privacy for Australia?' (2002) 26 Melbourne University Law Review 381; Peter Bartlett, 'Privacy Down Under' (2010) 3 Journal of International Media and Entertainment Law 145; Australian Law Reform Commission, For Your Information: Australian Privacy Law and Practice, Report No 108 (2008) vol 3, 2535; Victorian Law Reform Commission, Surveillance in Public Places, Final Report No 18 (2010) 128; New South Wales Law Reform Commission, Invasion of Privacy, Report No 120 (2009).
} 
action. ${ }^{2}$ This article seeks to redress that omission, by examining various remedies which could be granted if a statutory cause of action were enacted to protect personal privacy. The article begins by analysing the de facto personal privacy protection that exists under the confidentiality doctrine in order to explore privacy protection as it currently stands in Australia. It is argued that the enactment of a statutory cause of action for invasions of personal privacy would not only clarify the area of personal privacy law in Australia, but also improve the remedial framework available for breaches of personal privacy, which is currently unsettled and, more importantly, unsatisfactory. After assessing various remedial options for breaches of personal privacy, this article contends that if the legislature introduces a statutory cause of action for the invasion of personal privacy, there should be a broad range of remedies available, including punitive monetary awards, known as exemplary damages. Finally, it is argued that providing the courts with a flexible remedial framework will ensure that any reform of personal privacy law will cater to the ever-changing technological landscape that continually gives rise to novel privacy challenges.

\section{Current Protection of Personal Privacy in AUSTRALIA}

Determining the availability and strength of privacy protection is made difficult by the fact that privacy is an inherently hard concept to define. ${ }^{3}$ Leading American tort scholar William Prosser wrote in 1960 that the law of privacy and the torts which protected privacy could be broken into four categories:

1. Intrusion upon the plaintiff's seclusion or solitude, or into his private affairs.

2. Public disclosure of embarrassing private facts about the plaintiff.

3. Publicity which places the plaintiff in a false light in the public eye.

\footnotetext{
${ }^{2}$ See, Victorian Law Reform Commission, above n 1, 26 and 162. Of 44 submissions (at 26), the Commission 'received only one submission about the remedies that should be available when there has been a serious invasion of privacy': at 162. Cf Normann Witzleb, 'Monetary Remedies for Breach of Confidence in Privacy Cases' (2007) 27 Legal Studies 430; Michael Tilbury, 'Remedies for Breach of Confidence in Privacy Contexts' (2010) 15 Media and Arts Law Review 290.

${ }^{3}$ Lenah Game Meats (2001) 208 CLR 199, 225-6 (Gleeson CJ).
} 
4. Appropriation, for the defendant's advantage, of the plaintiff's name or likeness. $^{4}$

Nearly all US states recognise some or all of these privacy rights, either at common law or under statute. ${ }^{5}$ In Australia, personal privacy of this kind is not a statutory right, ${ }^{6}$ has no explicit constitutional protection and no appellate court has held it to exist as a stand-alone right. ${ }^{7}$ However, aspects of personal privacy are protected by the Privacy Act 1988 (Cth), some state legislation ${ }^{8}$ and the equitable confidentiality doctrine.

\section{A Privacy Protection through the Confidentiality Doctrine}

Victoria Park and Recreation Grounds Co Limited v Taylor ('Victoria Parkv Taylor' $)^{9}$ was considered for many years to block the recognition of a common law right to privacy in Australia. ${ }^{10}$ The defendant in the case had broadcast radio reports of horse races taking place on the plaintiff's premises, without the permission of the plaintiff. ${ }^{11}$ The plaintiff had sought an injunction to restrain the broadcasts, claiming that the defendant's conduct amounted to a nuisance. ${ }^{12}$ In rejecting the notion that privacy could be protected under the head of nuisance Latham CJ remarked that the authorities cited failed to show that 'any general right of privacy exists' in Australia. ${ }^{13}$ However, in Australian Broadcasting Corporation v Lenah Game Meats

\footnotetext{
${ }^{4}$ William Prosser, 'Privacy' (1960) 48 California Law Review 383, 389.

${ }^{5} \mathrm{~W}$ Page Keeton et al (eds), Prosser and Keeton on the Law of Torts (West Publishing, $5^{\text {th }}$ ed, 1984) 851.

${ }^{6}$ Bartlett, above n 1, 163.

${ }^{7}$ Ibid 151.

${ }^{8}$ See, eg, Privacy and Personal Information Act 1998 (NSW); Information Privacy Act 2000 (Vic); Information Privacy Act 2009 (Qld); Surveillance Devices Act 2007 (NSW); Surveillance Devices Act 1999 (Vic); Surveillance Devices Act 1998 (WA).

${ }^{9}$ (1937) 58 CLR 479.

${ }^{10}$ Lenah Game Meats (2001) 208 CLR 199, 277 (Kirby J); Bartlett, above n 1, 147; Cf Church of Scientology Inc $v$ Woodward (1982) 154 CLR 25, 68 (Murphy J) where it was stated that if an officer of ASIO disseminated personal information in a manner ultra vires to their office, a claimant may be entitled to a remedy under the 'developing' tort of 'unjustified invasion of privacy'.

${ }^{11}$ Victoria Park $v$ Taylor (1937) 58 CLR 479, 480-1.

${ }^{12}$ Ibid 481-2.

${ }^{13}$ Ibid 496.
} 
('Lenah Game Meats'), the High Court of Australia rejected the premise that Victoria Park $v$ Taylor stood in the path of an enforceable right of privacy. ${ }^{14}$

In Lenah Game Meats, the High Court upheld a trial decision refusing to grant an injunction to restrain the defendant from publishing footage of possums being processed in an abattoir, footage which had been illegally obtained by an unknown trespasser and later supplied to a national broadcaster. In refusing the application Gummow and Hayne JJ held that a tort of privacy, if one existed, would benefit natural persons, not artificial persons such as the plaintiff. ${ }^{15}$ Therefore, their Honours stated that it was unnecessary to determine whether or not a tort protecting privacy should be recognised on the facts before the court. ${ }^{16}$ Gleeson CJ openly invited the development of the general law protection of privacy stating, "the law should be more astute than in the past to identify and protect interests of a kind which fall within the concept of privacy'. ${ }^{17}$ Thus, the High Court opened the door to further privacy protection in Australia, but did not clarify what form this should take. No appellate court since Lenah Game Meats has held that a common law right to privacy exists. Instead, privacy has been given de facto protection through the breach of confidence doctrine. ${ }^{18}$

Breach of confidence was described by Megarry $\mathrm{J}$ in Coco $v$ A $N$ Clark Engineers Limited to require information:

1. that has the necessary quality of confidence;

2. that has been imparted in circumstances importing an obligation of confidence; and

3. that has been subject to an unauthorised use, to the detriment of the party communicating it. ${ }^{19}$

The current operation of the confidentiality doctrine is said to afford privacy protection because, in order to establish the relationship of confidence in the second limb of the test, a plaintiff need only prove that a defendant obtained information in circumstances under which the defendant knew, or ought to

\footnotetext{
${ }^{14}$ Lenah Game Meats (2001) 208 CLR 199, 248 (Gummow and Hayne JJ), 321-2 (Callinan J). See, for a more qualified view, 277 (Kirby J).

${ }^{15}$ Ibid 258. See also, 279 (Kirby J).

${ }^{16}$ Ibid.

${ }^{17}$ Ibid 225.

${ }^{18}$ Giller v Procopets (2008) 24 VR 1, 112-3 (Neave JA).

${ }^{19}$ [1969] RPC 41, 47.
} 
have known, from the manner in which the information was obtained, that the information was private. ${ }^{20}$ This negates the need for a pre-existing relationship to exist for a person to prove an actual or apprehended breach of confidence.

Decisions since Lenah Game Meats show that a wide variety of information will meet the threshold 'quality of confidence' requirement in the first limb of the test from Coco v A N Clark Engineers Limited. This includes information about sexual relations and health records. ${ }^{21}$ A few limited defences to breach of confidence exist; namely that the information is already in the public domain or that it exposes an 'iniquity'. ${ }^{22}$

The protection of personal privacy provided under the confidentiality doctrine is incomplete in that the doctrine does not cover some situations that a separate tort of privacy would. ${ }^{23}$ Consider the situation where a landlord, standing outside the leased property, uses a peephole covered by a two-way mirror to secretly watch a tenant in the bathroom. ${ }^{24}$ In this scenario, breach of confidence would, at best, import an obligation on the landlord not to communicate or disclose any confidential information obtained in the course of the viewing. If the landlord had videotaped or recorded conversation through the peephole the tenant may have recourse under state legislation that regulates use of surveillance devices. ${ }^{25}$ However, in the absence of a recording or disclosure, the tenant has no recourse against an action based purely on the invasion of privacy. The existence of gaps in the law, such as in this peephole example, is one reason - along with making the law more holistic in the area of personal privacy - why various commentators have

\footnotetext{
${ }^{20}$ Lenah Game Meats (2001) 208 CLR 199, 225 (Gleeson CJ); Giller v Procopets (2008) 24 VR 1, 102 (Neave JA). See also Coco v A N Clark Engineers Limited [1969] RPC 41, 48 (Megarry J); Attorney-General v Guardian Newspapers Limited (No 2) [1990] 1 AC 109, 291 (Lord Goff).

${ }^{21}$ Giller v Procopets (2008) 24 VR 1; Australian Football League v The Age Company Ltd (2006) 15 VR 419.

${ }^{22}$ Australian Football League v The Age Company Ltd (2006) 15 VR 419, 436-7.

${ }^{23}$ Victorian Law Reform Commission, above n 1, 145 [7.105].

${ }^{24}$ This situation is similar to that in the Canadian case Lee $v$ Jacobson (1992) 87 DLR $\left(4^{\text {th }}\right) 401$ (British Columbia Supreme Court).

${ }^{25}$ See, eg, Surveillance Devices Act 1999 (Vic) s 7; Surveillance Devices Act 2007 (NSW) s 8; Surveillance Devices Act 1998 (WA) s 6.
} 
suggested that a separate cause of action for privacy should be recognised by the judiciary or enacted by the legislature in Australia. ${ }^{26}$

\section{B Tort of Invasion of Privacy in Australia}

Despite the invitation in Lenah Game Meats for courts to develop the law of privacy, only two trial judgments have held that a tort of privacy exists under the common law of Australia. The first, in Grosse v Purvis, involved two parties to a sexual relationship which had come to an end. ${ }^{27}$ The plaintiff accused the defendant of stalking her and cited over 70 incidents of threatening conduct, of which 35 were found at trial to be partially or fully corroborated. ${ }^{28}$ The trial judge found that the plaintiff had developed a posttraumatic stress disorder as a result of the defendant's conduct and awarded $\$ 178000$ in damages, which included an award based on 'the actionable right of an individual person to privacy'. ${ }^{29}$ Skoien SJ stated that he was taking a 'logical and desirable step' in recognising a separate tort of privacy. ${ }^{30}$ His Honour was of the opinion that the essential elements of a new cause of action for invasion of privacy should be:

a) a willed act by the defendant,

b) which intrudes upon the privacy or seclusion of the plaintiff,

c) in a manner which would be considered highly offensive to a reasonable person of ordinary sensibilities,

d) and which causes the plaintiff detriment in the form of mental, psychological or emotional harm or distress which prevents or hinders the plaintiff from doing an act which she is lawfully entitled to do. ${ }^{31}$

A defence of public interest was said to be available to this tortious claim for invasion of privacy, but Skoien SJ held that, on the facts, it was not available. ${ }^{32}$

\footnotetext{
${ }^{26}$ Jillian Caldwell, 'Protecting Privacy Post Lenah: Should the Courts Establish a New Tort or Develop Breach of Confidence?' (2003) 26(1) University of New South Wales Law Journal 90; Victorian Law Reform Commission, above n 1, 145-6.

27 [2003] Aust Tort Reports $981-706,64137$ [21]-[24] (a decision of the District Court of Queensland).

${ }^{28}$ Ibid 64174 [339].

${ }^{29}$ Ibid 64187 [442].

${ }^{30}$ Ibid.

${ }^{31}$ Ibid 64187 [444].
} 
The second case was Jane Doe v Australian Broadcasting Corporation ${ }^{33}$ which involved the publication of information in radio news bulletins by the defendant broadcaster, identifying the plaintiff as a rape victim. ${ }^{34}$ The defendant and its two employees were held to be in breach of section 4(1A) of the Judicial Proceedings Reports Act 1958 (Vic), which prohibits identification of victims of sexual offences. ${ }^{35}$ In addition, Judge Hampel of the County Court of Victoria held that the defendants had 'breached the plaintiff's privacy by the unjustified publication of personal information. ${ }^{36}$ Unlike Skoien SJ in Grosse v Purvis, Judge Hampel did not list the indicia of the action for privacy which she held to exist, but described the wrong as 'the publication of personal information, in circumstances where there was no public interest in publishing it, and where there was a prohibition on its publication'. ${ }^{37}$

In both cases, the judges noted that Lenah Game Meats had invited the recognition of a tort of invasion of privacy and that the respective facts had proven sufficient for them to respond to that invitation. ${ }^{38}$ Despite these cases, it is unclear whether a tort of invasion of privacy or a similar cause of action would be upheld at an appellate level. ${ }^{39}$ Furthermore, any future development of privacy protection under common law is dependant on adequate test cases being litigated and is therefore likely to be slow and piecemeal. ${ }^{40}$

\section{The Absence of the Misuse of Private Information Doctrine in Australia}

The Australian position in relation to confidentiality can be contrasted with developments in the United Kingdom. There the judiciary has recognised privacy as worthy of protection in its own right, but has stopped short of recognising a common law tort of privacy, ${ }^{41}$ as has occurred in New

\footnotetext{
${ }^{32}$ Ibid 64187 [447].

${ }^{33}$ [2007] VCC 281.

${ }^{34}$ Ibid [2].

${ }^{35}$ Ibid [80]-[81].

${ }^{36}$ Ibid [164].

${ }^{37}$ Ibid [163].

${ }^{38}$ Ibid [157]; Grosse v Purvis [2003] Aust Tort Reports $₫ 81-706,64186$ [435], 64187 [442].

${ }^{39}$ Lenah Game Meats (2001) 208 CLR 199, 225-6 (Gleeson CJ); Giller v Procopets (2008) 24 VR 1, 112-3 (Neave JA); Kalaba v Commonwealth [2004] FCAFC 326; Bartlett, above n 1, 172; Australian Law Reform Commission, above n 1, vol 3, 2552.

${ }^{40}$ Victorian Law Reform Commission, above n 1, 130 [7.14].

${ }^{41}$ Campbell v MGN Ltd [2004] 2 AC 457, 472 [46] (Lord Hoffmann). See also Wainwright $v$ Home Office [2004] 2 AC 406, 424 [35].
} 
Zealand. ${ }^{42}$ Developments in the United Kingdom have occurred in light of the Human Rights Act 1998 (UK), which domestically enshrines the European Convention for the Protection of Human Rights and Fundamental Freedoms 1950 ('ECHR'). ${ }^{43}$ The most important aspects of the ECHR in relation to privacy are Article 8, which guarantees a right of respect for an individual's private and family life, and Article 10, which protects freedom of expression. The separate cause of action now available in the United Kingdom is an evolution of the confidentiality doctrine and has been described as, among other things, a tort of misuse of private information. ${ }^{44}$ Under this cause of action a court must first determine whether, in the circumstances, there exists 'a reasonable expectation of privacy' ${ }^{45}$ If an expectation is found to exist, the court must balance this against any countervailing considerations of public interest, which would justify the specific intrusion into another's privacy. ${ }^{46}$ Any attempt to institute action for misuse of private information is afflicted by questions of the action's jurisprudential underpinning and the extent to which it is bound by the rules of equity or tort; ${ }^{47}$ nevertheless it provides a more clear form of privacy protection than exists in Australia via confidentiality.

\section{CURRENT Remedial Framework}

The complicated jurisdictional underpinning of breach of confidence has given rise to considerable academic discussion regarding the availability of various remedies under this doctrine. ${ }^{48}$ In general, injunctions are sought where there is an apprehended breach of privacy. Once confidentiality has been breached, aggrieved persons often seek pecuniary relief; however the courts are limited in the types of monetary awards they can grant.

\section{A Injunctions}

Being an equitable remedy, injunctions are readily available in confidentiality cases. ${ }^{49}$ Injunctions, particularly interim injunctions, have historically been

\footnotetext{
${ }^{42}$ Hosking $v$ Runting [2005] 1 NZLR 1, 32 (Court of Appeal).

${ }^{43}$ Douglas v Hello! Ltd [2001] QB 967, 997 [111] (Sedley LJ).

${ }^{44}$ Campbell v MGN Ltd [2004] 2 AC 457, 465 [14] (Lord Nicholls).

${ }^{45}$ Mosley v News Group Newspapers Ltd [2008] EWHC 1777 (QB) (24 July 2008) [7].

${ }^{46}$ Ibid [7]-[15].

${ }^{47}$ See Witzleb, above n 2, 439.

${ }^{48}$ Mathew Broderick, 'Equitable Compensation - Its Place in the Remedial Sphere' (2005) 33 Australian Business Law Review 369; Peter Devonshire, 'Pecuniary Remedies for Breach of Confidence' (2010) 21 King's Law Journal 355; Tilbury, above n 2.

49 Tilbury, above n 2, 294.
} 
regarded as the most important remedy for a plaintiff claiming a breach, or threatened breach, of personal privacy. ${ }^{50}$ This is based on the premise that, once confidentiality has been breached - and in this respect the breach of confidence is different from a defamation - nothing can be done to compensate a plaintiff. ${ }^{51}$

Jurisprudence in Australia, the United Kingdom and the European Union makes it clear that a court is unlikely to, by way of injunction, attempt to prevent publication or communication of material already in the public domain, since public availability strips information of its confidentiality. ${ }^{52}$ For example, in the high profile British case of Max Mosley, Eady $\mathrm{J}$ found that imposing an injunction to restrict publication of footage of Mosley engaging in a orgy would 'merely be a futile gesture' ${ }^{53}$ because the footage had already 'entered the public domain to the extent that there [was], in practical terms, no longer anything which the law [could] protect' ${ }^{54}$ However, more than limited or partial dissemination must occur for information to be considered in the public domain. ${ }^{55}$ For example, publication of information on the internet will not automatically mean that the information has lost its quality of confidence. $^{56}$

The rise of online media has meant that injunctions are often an ineffective remedial mechanism in the digital age. ${ }^{57}$ They can become difficult to enforce once obtained, ${ }^{58}$ as seen during the Ryan Giggs saga.

\footnotetext{
${ }^{50}$ Helen Fenwick and Gavin Phillipson, Media Freedom under the Human Rights Act (Oxford University Press, 2006) 807; Eric Barendt, Freedom of Speech (Oxford University Press, 2nd ed, 2006) 137.

51 Gavin Phillipson, 'Max Mosley goes to Strasbourg: Article 8, Claimant Notification and Interim Injunctions' (2009) 1 Journal of Media Law 73, 74; Mosley $v$ News Group Newspapers Limited [2008] EWHC 1777 (QB) (24 July 2008) [230]-[231].

52 Australian Football League v The Age Company Ltd (2006) 15 VR 419, 427; Saltman Engineering Co Ltd v Campbell Engineering Co Ltd [1963] 3 All ER 413, 415 (Greene MR); Observer v United Kingdom (1992) 216 Eur Court HR (Ser A) ; Vereniging Weekblad Bluf! v Netherlands (1995) 306-A Eur Court HR (Ser A).

${ }^{53}$ Mosley v News Group Newspapers Limited [2008] EWHC 687 (QB) (4 April 2008) [36].

${ }^{54}$ Ibid.

55 Australian Football League v The Age Company Ltd (2006) 15 VR 419, 431-3; Barclays Bank plc v Guardian News \& Media Ltd [2009] EWHC 591 (QB) [22].

${ }^{56}$ Australian Football League v The Age Company Ltd (2006) 15 VR 419, 433.

${ }^{57}$ Mosley v News Group Newspapers Limited [2008] EWHC 1777 (QB) (24 July 2008); CTB v News Group Newspapers Ltd [2011] EWHC 1232 (16 May 2011).

58 I C F Spry, The Principles of Equitable Remedies: Specific Performance, Injunctions, Recitification and Equitable Damages (Lawbook, 8th ed, 2010) 405.
} 
In April 2011 the British newspaper The Sun published a story about a sexual relationship between an unnamed football star and a reality TV star. ${ }^{59}$ The player in question, Ryan Giggs, went to court and was granted an injunction restraining the defendants from identifying him or further publishing accounts of the sexual relationship. ${ }^{60}$ After assessing whether the injunction should be refused because the relevant material was already in the public domain, ${ }^{61}$ Eady $\mathrm{J}$ emphasised that, despite some publication, some privacy can still remain. ${ }^{62}$ With this in mind, Eady $\mathrm{J}$ granted the injunction.

Nevertheless, Giggs was identified as the unnamed footballer on the internet, by more than 75000 Twitter users, among others. ${ }^{63}$ This prompted the newspaper to apply to have the injunction lifted. ${ }^{64}$ Eady $\mathrm{J}$ refused to alter the anonymised injunction, finding that modern privacy law in the United Kingdom "is not concerned solely with information or "secrets": it is also concerned importantly with intrusion'. ${ }^{65}$ Despite the injunction not having named the plaintiff, John Hemming MP named Giggs under the cloak of parliamentary privilege. ${ }^{66}$ In refusing a further application by the defendant newspaper to lift the injunction, Tugendhat $\mathrm{J}$ noted that the court order had 'not protected the claimant and his family from taunting on the internet ${ }^{67}$ but thought it was 'still effective to protect them from taunting and other intrusion and harassment in the print media' ${ }^{68}$ However, the mainstream English press began naming Giggs based on media immunity in the reporting of parliamentary proceedings. ${ }^{69}$ The Giggs case shows that, despite the imposition of court ordered injunctions, personal privacy can easily and rapidly be breached by an increasingly interconnected public.

\footnotetext{
${ }^{59}$ CTB v News Group Newspapers Ltd [2011] EWHC 1232 (QB) (16 May 2011) [1].

${ }^{60}$ Ibid. The order also afforded what has become known as a 'super injunction', which restrains publication of the existence of the injunction.

${ }^{61}$ Ibid [24]-[33].

${ }^{62}$ Ibid [28].

${ }^{63}$ BBC News UK Ryan Giggs Named by MP as Injunction Footballer (23 May 2011), $<$ http://www.bbc.co.uk/news/uk-13503847>.

${ }^{64}$ CTB v News Group Newspapers Ltd [2011] EWHC 1326 (QB) (23 May 2011).

${ }^{65}$ Ibid [23].

${ }^{66}$ CTB v News Group Newspapers Ltd [2011] EWHC 1334 (QB) (23 May 2011) [2].

${ }^{67}$ Ibid [3].

${ }^{68}$ Ibid.

${ }^{69}$ See Gordon Rayner, Ryan Giggs Named as Premier League Footballer in Gagging Order Row, (23 May 2011) The Telegraph <http://www.telegraph.co.uk/technology/twitter/ 8531175/Ryan-Giggs-named-as-Premier-League-footballer-in-gagging-order-row.html>; BBC News UK, Ryan Giggs Named by MP as Injunction Footballer (23 May 2011) $<\mathrm{http}: / /$ www.bbc.co.uk/news/uk-13503847>.
} 
While injunctions are a necessary element to any legal regime protecting personal privacy, in the words of Normann Witzleb, 'the raison d'être of an injunction is its coercive character. Where an injunction is unenforceable, it is difficult to see that it has greater vindicatory effect than an award of damages, or even a declaration'. ${ }^{70}$

\section{B Compensatory Damages}

While Australian courts have held that damages are available to compensate for the loss that a plaintiff has suffered through a breach of confidence, ${ }^{71}$ there is debate about the foundation, if any, on which such damages should be awarded. $^{72}$ A popular line of reasoning suggests that courts may award damages under modern equivalents of the Chancery Amendment Act 1858 (UK) ('Lord Cairns' Act'), ${ }^{73}$ which give courts the power to award damages in lieu of, or in addition to, an injunction, for equitable breaches. ${ }^{74}$ Another argument is that 'equitable damages', based on equity's inherent power to make compensatory awards, are available under the confidentiality doctrine. ${ }^{75}$

The difficulty of articulating the correct grounding for awards of damages in breach of confidence matters is compounded by the fact that plaintiffs will generally be seeking monetary compensation for 'mere distress' rather than for pecuniary loss or actual injury caused by the defendant's wrongdoing. Whether equitable compensation is available for mere distress is not settled, and tort law has allowed damages in the absence of actual harm only for certain torts such as trespass, assault and defamation. ${ }^{76}$ In Giller v Procopets, Neave JA looked to English case law in considering the grounds on which damages could be awarded for breach of confidence, stating:

English authorities assume that 'damages' are recoverable for 'mere distress' not amounting to psychiatric injury, but do not explain whether the

\footnotetext{
${ }^{70}$ Normann Witzleb, 'Equity does not Act in Vain: An Analysis of Futility Arguments in Claims for Injunctions' (2010) 32 Sydney Law Review 503, 506.

${ }^{71}$ Giller v Procopets (2008) 24 VR 1, 96 (Neave JA).

72 Tilbury, above n 2, 291.

${ }^{73}$ See, eg, Supreme Court Act 1986 (Vic) s 38; Supreme Court Act 1970 (NSW) s 68; Supreme Court Act 1935 (SA) s 30.

${ }^{74}$ Giller v Procopets (2008) 24 VR 1, 94-6 (Neave JA).

${ }^{75}$ Ibid 99-100 (Neave JA).

${ }^{76}$ See Danuta Mendelson, The New Law of Torts (Oxford University Press, 2007) 6; Witzleb, above $\mathrm{n} 2$.
} 
basis for such an award is an order for equitable compensation, damages under Lord Cairns' Act, or on some other basis. ${ }^{77}$

In the light of this unclear authority, and based on the call by Gleeson CJ in Lenah Game Meats to develop recognised causes of action to meet modern privacy situations, Neave JA found that damages should be available under Lord Cairns' Act for breach of confidence occasioning distress. ${ }^{78}$ In addition, Neave and Ashley JJA held that equitable compensation should be available for breach of confidence. ${ }^{79}$ Neave JA concluded that:

An inability to order equitable compensation to a claimant who has suffered distress would mean that a claimant whose confidence was breached before an injunction could be obtained would have no effective remedy. ${ }^{80}$

Michael Tilbury has argued that Neave JA's conclusion was 'unconvincing' because it relied, in part, on judicial statements from the United Kingdom that equitable compensation can be awarded for mere distress in cases involving misuse of private information. Such authority has developed in light of the Human Rights Act (UK) and is therefore 'inapplicable' in Australia. ${ }^{81}$

\section{Aggravated and Exemplary Damages}

While it has been said that exemplary damages have become 'well and truly part of the common law of Australia" ${ }^{82}$ they are not available in breach of confidence claims. ${ }^{83}$ Australian judges abide by the rule, as described by Heydon JA in Harris $v$ Digital Pulse Pty Ltd, that 'there is no power in the law ... to award exemplary damages for equitable wrongs'. ${ }^{84}$ This is based on the notion that the punitive aims of exemplary damages are improper in equity. Nevertheless, following the distinction made by Lord Devlin in Rookes $v$ Barnard ${ }^{85}$ between 'exemplary' damages and 'aggravated'

\footnotetext{
${ }^{77}$ Giller v Procopets (2008) 24 VR 1, 99-100.

${ }^{78}$ Ibid 101-2.

${ }^{79}$ Ibid 100 (Neave JA), 33-4 (Ashley JA).

${ }^{80}$ Ibid 100.

${ }^{81}$ Tilbury, above n 2, 291-2.

${ }^{82}$ Harris v Digital Pulse Pty Ltd (2003) 56 NSWLR 298, 322 (Mason P).

${ }^{83}$ Giller v Procopets (2008) 24 VR 1, 33 (Ashley JA).

${ }^{84}$ Harris v Digital Pulse Pty Ltd (2003) 56 NSWLR 298, 422.

${ }^{85}$ [1964] AC 1129.
} 
damages, ${ }^{86}$ courts have awarded aggravated damages for breaches of confidence. ${ }^{87}$

In Rookes $v$ Barnard Lord Devlin distinguished compensatory damages from exemplary damages with punitive aims, which he held should be awarded only in three discrete scenarios: where oppressive, arbitrary or unconstitutional acts had been carried out by servants of the government; where the defendant had calculated that the profit made from his or her conduct would or might exceed any compensatory damages; and where statute allowed for such damages. ${ }^{88}$ On the other hand, aggravated damages were said to fall under the compensatory category, as they were said to compensate the plaintiff for harm caused which had been aggravated by the manner in which the defendant had acted in doing the wrong. So, while they may appear to punish the defendant's behaviour, aggravated damages are actually considered compensatory, as they seek to redress further damage done to the plaintiff. $^{89}$

In explaining the manner in which aggravated and exemplary damages are assessed, the High Court - in the leading Australian case on point, Gray v Motor Accident Commission - stated that:

In considering whether to award exemplary damages, the first, if not the principal, focus of the enquiry is upon the wrongdoer, not upon the party who was wronged. (The reaction of the party who is wronged to highhanded or deliberate conduct may well be a reason for awarding aggravated damages in further compensation for the wrong done. But it is not ordinarily relevant to whether exemplary damages should be allowed). ${ }^{90}$

Exemplary damages have also been distinguished from aggravated damages by the suggestion that they 'apply only where the conduct of the defendant merits punishment, which is only considered to be so where his conduct is wanton, as where it discloses fraud, malice, violence, cruelty, insolence or the like'. ${ }^{91}$ In reality, exemplary and aggravated damages often address similar

\footnotetext{
${ }^{86}$ Uren v John Fairfax \& Sons Pty Ltd (1966) 117 CLR 118, 149 (Windeyer J) ('Uren v John Fairfax').

${ }^{87}$ Giller v Procopets (2008) 24 VR 1, 106 (Neave JA).

${ }^{88}$ [1964] AC 1129, 1226-7.

${ }^{89}$ Uren v John Fairfax (1966) 117 CLR 118, 149 (Windeyer J)

90 (1998) 196 CLR 1, 7 (Gleeson CJ, McHugh, Gummow and Hayne JJ).

${ }^{91}$ John Mayne and Harvey McGregor, Mayne and McGregor on Damages (Sweet \& Maxwell, $12^{\text {th }}$ ed, 1961), 196. See also, Whitfeld v De Lauret \& Co Ltd (1920) 29 CLR 71, 77; Uren v John Fairfax (1966) 117 CLR 118, 129 (Taylor J).
} 
conduct, ${ }^{92}$ being wrongs committed in a 'highhanded, malicious, insulting or oppressive manner'. ${ }^{93}$ It is clever labelling that has enabled the judiciary to support the fallacy that the two have 'separate and mutually exclusive meanings'. 94

While the High Court of Australia has maintained the distinction between exemplary and aggravated damages, it has rejected the restriction of exemplary damages to Lord Devlin's three categories. ${ }^{95}$ In Uren $v$ John Fairfax \& Sons Pty Ltd ('Uren v John Fairfax') Windeyer J articulated two factors that must be met before a court can award exemplary damages. ${ }^{96}$ Firstly, the wrong must be of a kind for which exemplary damages might be given. ${ }^{97}$ As breach of confidence is an equitable cause of action, judges are barred from awarding this remedy. On the other hand, if privacy is recognised in Australia under tort law, exemplary damages may be available. ${ }^{98}$ This was the case in Grosse v Purvis, where Skoien SJ awarded \$20 000 as an 'exemplary sanction' directed at the defendant's conduct. ${ }^{99}$

The second factor required by Windeyer J in Uren $v$ John Fairfax to justify a verdict for exemplary damages was positive misconduct. ${ }^{100}$ This second factor is what shifted the law in Australia away from the three strict categories of wrongful conduct of Rookes $v$ Barnard. Australian courts have since accepted that a range of misconduct can satisfy this second requirement, such as actions which amount to a 'conscious and contumelious disregard for the plaintiff's rights'. ${ }^{101}$

\footnotetext{
${ }^{92}$ Uren v John Fairfax (1966) 117 CLR 118, 151-2 (Windeyer J).

${ }^{93}$ Broome v Cassell \& Co Limited (No. 1) [1972] AC 1027, 1085 (Lord Reid). See generally Tilbury, above n 2, 291.

${ }^{94}$ Broome v Cassell \& Co Limited (No. 1) [1972] AC 1027, 1072 (Hailsham LC).

${ }^{95}$ Gray v Motor Accident Commission (1998) 196 CLR 1, 8 (Gleeson CJ, McHugh, Gummow and Hayne JJ).

96 (1966) 117 CLR 118, 153-4.

${ }^{97}$ Ibid 153.

98 Exemplary damages have been held to be available for a number of torts, including defamation and trespass to the person and to land. See, Uren $v$ John Fairfax (1966) 117 CLR 118, 158 (Owen J); Fontin v Katapodis (1962) 108 CLR 177, 183; Johnstone v Stewart [1968] SASR 142; XL Petroleum (NSW) Pty Ltd v Caltex Oil (Australia) Pty Ltd (1985) 155 CLR 448.

99 [2003] Aust Tort Reports $₫ 81-706,64191$ [482].

${ }^{100}$ (1966) 117 CLR 118, 154.

${ }^{101}$ XL Petroleum (NSW) Pty Ltd v Caltex Oil (Australia) Pty Ltd (1985) 155 CLR 448, 471 (Brennan J); See also, Lamb v Cotogno (1987) 164 CLR 1, 8; Hospitality Group Pty Ltd v
} 


\section{Account of Profits}

An alternative to damages is an award of 'account of profits', which has traditionally acted to strip an unjustly enriched party of profit wrongfully acquired through a breach of equitable right. ${ }^{102}$ It has been said by Lord Bridge that, where an injunction is futile in a breach of confidence context, the correct remedy would be an account of profits. ${ }^{103}$ However, information disclosed in breach of confidence may not have an easily quantifiable value and any profit flowing from the breach may be difficult to determine. For example, how would one determine the profit made by a newspaper which publishes a story about a celebrity sex scandal in breach of confidence? The story is just one factor impacting on readership and advertising revenue for that day or week. Furthermore, as in the Giggs example, widespread breach of confidence over the internet may not lead to any party making a discernible profit.

Also, in bringing an action for breach of confidence a plaintiff must elect either damages or an account of profits - the two act as alternative remedies. ${ }^{104}$ The lack of certainty in assessing profit and the increasing acceptance of damages as a legitimate remedy makes it more likely that claimants will elect to pursue damages rather than an account of profits in confidentiality matters.

\section{CuRrent Proposals for LaW Reform}

Privacy has become a buzz topic in Australian law reform circles in recent years, particularly since the Australian Law Reform Commission ('ALRC') released a comprehensive report into privacy in August 2008. ${ }^{105}$ One of the recommendations of the ALRC was that the federal government enact a statutory cause of action for serious invasions of the privacy of natural persons, where the action of the respondent has been reckless or intentional. ${ }^{106}$ Under the legislation suggested by the ALRC a claimant would have to show that, in the circumstances, there was a reasonable expectation of privacy and that the act or conduct complained of was highly offensive to a reasonable

\footnotetext{
Australian Rugby Union Ltd (2001) 110 FCR 157, 190-1; Gray v Motor Accidents Commission (1998) 196 CLR 1, 7 (Gleeson CJ, McHugh, Gummow and Hayne JJ).

${ }^{102}$ Coldbeam Palmer Ltd v Stock Affiliates Pty Ltd (1968) 122 CLR 25, 32 (Windeyer J).

${ }^{103}$ Attorney General v Guardian Newspapers Ltd [1987] 3 All ER 316, 345.

${ }^{104}$ Attorney General v Guardian Newspapers Ltd (No 2) [1990] 1 AC 109, 286; Mosley v News Group Newspapers Ltd [2008] EWHC 1777 (QB) (24 July 2008) [175].

${ }^{105}$ Australian Law Reform Commission, above $\mathrm{n} 1$.

${ }^{106}$ Ibid vol 3, 2535, 2584-6.
} 
person of ordinary sensibilities. ${ }^{107}$ While 'serious invasion' was not defined, the ALRC suggested a list of examples of possible invasions of privacy: serious interference with home or family life; unauthorised surveillance; interference with and misuse or disclosure of private correspondence; and disclosure of sensitive facts relating to an individual's private life. ${ }^{108}$ In determining whether an individual's privacy has been invaded under the proposed cause of action, a court would have to determine whether the claimant's privacy outweighs other matters of public interest, including the public's right to be informed about matters of public concern and freedom of expression. ${ }^{109}$

In 2009 the New South Wales Law Reform Commission ('NSWLRC') also recommended a cause of action to protect against invasions of privacy. ${ }^{110}$ The NSWLRC suggested a general cause of action that sought to protect against invasions of information privacy and intrusions on seclusion. ${ }^{111}$ After stressing its broad support for a statutory cause of action, ${ }^{112}$ the Victorian Law Reform Commission ('VLRC'), in 2010, recommended that two causes of action be enacted - one for misuse of private information and another for intrusion upon seclusion. ${ }^{113}$ Then, in September 2011, the federal government released an Issues Paper seeking public views as to whether the federal parliament should create a right for individuals to seek redress from another person who seriously invades their privacy. ${ }^{114}$

Enacting a statutory cause of action for serious invasions of privacy could fill some of the gaps in privacy protection that exist in Australia, ${ }^{115}$ as exemplified by the peephole scenario discussed above. Any new legislation will be able to cherry-pick the most appropriate remedies to ensure the effectiveness of the new cause of action, while simultaneously freeing the

\footnotetext{
${ }^{107}$ Ibid vol 3, 2565, 2584 [Recommendation 74-2].

${ }^{108}$ Ibid vol 3, 2584 [Recommendation 74-1].

109 Ibid.

${ }^{110}$ New South Wales Law Reform Commission, above $\mathrm{n} 1$.

${ }^{111}$ Ibid 21.

${ }^{112}$ Victorian Law Reform Commission, above n 1, 145-6.

${ }^{113}$ Ibid $147-51$.

${ }^{114}$ Brendan O'Connor, 'A Commonwealth Statutory Cause of Action for Serious Invasion of Privacy' (Issues Paper, Commonwealth Department of Prime Minister and Cabinet, September 2011).

${ }^{115}$ See Victorian Law Reform Commission, above n 1, 145 [7.105].
} 
courts from the need to justify orders by reference to, among other things, the historical split between law and equity. ${ }^{116}$

\section{Remedial PossibiLities}

Remedies available for breach of confidence are often an inadequate or unsatisfactory means of making good intrusions into personal privacy. Michael Tilbury has stated that 'if privacy and confidentiality are simply different concepts ... it is difficult to believe that a uniform pattern of remedies is possible in respect of both. ${ }^{117}$ Therefore, a remedial regime provided for a right to privacy should not be constrained by the jurisprudential underpinnings or historical understandings of confidentiality.

In recommending a statutory cause of action for serious invasion of privacy, the 2008 ALRC report suggested that a 'court should be empowered to choose the remedy that is most appropriate in the circumstances, free from the jurisdictional constraints that may apply to that remedy in the general law'. ${ }^{118}$ The report went on to state that courts should be empowered to grant one or more of the following remedies:

1. damages, including aggravated damages, but not exemplary damages;

2. an account of profits;

3. an injunction;

4. an order requiring the respondent to apologise to the claimant;

5. a correction order;

6. an order for the delivery up and destruction of material; and

7. a declaration.

The following section examines the remedies, including some in this list above, that could be employed in personal privacy matters. It contends that any statutory cause of action in Australia should be matched by a flexible

\footnotetext{
${ }^{116}$ See, eg, Douglas v Hello! Ltd (No 3) [2006] QB 125, 160.

117 Tilbury, above n 2, 294.

${ }^{118}$ Australian Law Reform Commission, above n 1, vol 3, 2585.
} 
remedial structure, because any right protected by law requires an adequate remedial arsenal. In the words of Gaudron and McHugh JJ:

If the courts of common law do not uphold the rights of individuals by granting effective remedies, they invite anarchy, for nothing breeds social disorder as quickly as the sense of injustice which is apt to be generated by the unlawful invasion of a person's rights. ${ }^{119}$

Injunctions are not examined in the following section, as this remedy is well accepted as important to privacy cases and faces limited attacks on its legitimacy or the extent to which it should be awarded. ${ }^{120}$ One the other hand, particular attention is given to exemplary damages, as this remedy has faced sustained criticism in privacy reform publications.

\section{A Compensatory and Aggravated Damages}

There is wide support for compensatory damages being available, even for mere distress, under any new statutory cause of action for privacy. ${ }^{121}$ This is because the difficulty in assessing damage done to feelings by a breach of personal privacy is outweighed by the understanding that any action for personal privacy not empowering courts to award damages would only provide hollow protection for aggrieved parties. ${ }^{122}$ If compensatory damages were available under a new cause of action, judges would be freed from assessing antiquated arguments on the availability of compensatory damages for personal privacy claims. ${ }^{123}$

The ALRC explicitly supported the availability of aggravated damages for breaches of personal privacy claims. ${ }^{124}$ In its initial consultation paper, the NSWLRC also suggested that aggravated damages should be available under its proposed statutory cause of action. ${ }^{125}$ However, its final report stated that a statutory cause of action would not need to explicitly afford claimants the

${ }^{119}$ Plenty v Dillon (1991) 171 CLR 635, 655.

${ }^{120}$ Victorian Law Reform Commission, above n 1, 161-2.

${ }^{121}$ Australian Law Reform Commission, above n 1, vol 3, 2585 [Recommendation 74-3(b)]; New South Wales Law Reform Commission, above n 1, 58-9; Victorian Law Reform Commission, above $\mathrm{n}$ 1, 163, [Recommendation 29].

${ }^{122}$ Cornelius $v$ De Taranto [2001] EMLR 12, [66]-[67], [69], cited with approval with regard to the availability of nominal damages only in confidentiality cases in Giller $v$ Procopets (2008) 24 VR 1, 100 (Neave JA).

${ }^{123}$ See, Victorian Law Reform Commission, above n 1, 161.

${ }^{124}$ Australian Law Reform Commission, above n 1, vol 3, 2585 [Recommendation 74-5(a)].

${ }^{125}$ New South Wales Law Reform Commission, Invasion of Privacy, Consultation Paper No 1 (2007) 202. 
right to aggravated damages, as the compensatory damages regime under it's suggested cause of action would aim to compensate injury to feelings or mental distress, which would include consideration of any aggravating conduct of the defendant. ${ }^{126}$ Therefore, aggravated damages were also supported in the NSWLRC report, but the need to label them 'aggravated' was not. ${ }^{127}$

As privacy cases are likely to be brought for injury to feelings or other noneconomic loss, which is inherently hard to assess, there is a legitimate fear that such awards could be inconsistent or excessive. It is for this reason that a statutory cause of action should cap the amount of damages available to plaintiff. The NSWLRC recommended that damages for non-economic loss flowing from privacy breaches should be capped at $\$ 150000$ plus indexing. ${ }^{128}$ Considering that defamation, like privacy, seeks to compensate the injured feelings of the plaintiff through damages, ${ }^{129}$ it would seem wise to cap the amount available under the two causes of action in equal amounts. The cap for damages arising from non-economic loss under the defamation statutes passed in Australian jurisdictions and known collectively as the 'uniform defamation laws' was $\$ 324000$ at 1 July $2011 .{ }^{130}$ Equally capping damages under the two causes of action would also prevent claimants cynically choosing the action which has a potentially higher award, where the facts could give rise to a claim in both defamation and privacy.

\footnotetext{
${ }^{126}$ New South Wales Law Reform Commission, above n 1, 59-60.

127 This is arguably also the case with the VLRC Report, which specifically excluded exemplary damages but did not discuss the availability, or not, of aggravated damages under the heading of compensatory damages.

${ }^{128}$ New South Wales Law Reform Commission, above n 1, 61-2.

${ }^{129}$ Carson v John Fairfax \& Sons Ltd (1993) 178 CLR 44, 60-1 (Mason CJ, Deane, Dawson and Gaudron JJ), 71 (Brennan J); McCarey v Associated Newspapers Ltd (No 2) [1965] 2 QB 86,104

130 See Defamation Act 2005 (Vic) s 35 (1), (3); Attorney-General (Vic), 'Defamation Act 2005: Declaration Under Section 35(3)' in Victoria, Victorian Government Gazette, No G 25, 23 June 2011, 1351-2; Defamation Act 2005 (NSW) s 35 (1),(3); Attorney-General (NSW), 'Defamation Act 2005: Order' in New South Wales, New South Wales Government Gazette, No 62, 24 June 2011, 4588; Defamation Act 2005 (Q1d) s 35 (1), (3); Paul Lucas, Deputy Premier and Attorney-General, Minister for Local Government and Special Minister of State, 'Defamation Act 2005: Declaration Under Section 35(3)' in Queensland, Queensland Government Gazette, No 65, 24 June 2011, 529; Defamation Act 2005 (WA) s 35 (1), (3); Attorney-General (WA), 'Defamation (Damages for Non-economic Loss) Order 2011' in Western Australia, Western Australian Government Gazette, No 111, 29 June 2011, 2597; Defamation Act 2005 (SA) s 33 (1), (3); Attorney-General (SA), 'Defamation Act 2005: Declaration Under Section 33 (3)' in South Australia, The South Australian Government Gazette, No 42, 23 June 2011, 2626; Defamation Act 2005 (Tas) s 35 (1), (3); 'Defamation Order 2011' in Tasmania, Tasmanian Government Gazette, No 21 159, 29 June 2011, 1009.
} 


\section{B Exemplary Damages}

Despite their long history in civil cases, ${ }^{131}$ exemplary damages are commonly categorised as inapposite and heretical to private law. ${ }^{132}$ Chief among the concerns about these awards is that they import criminal functions into the civil law. ${ }^{133}$ Yet the High Court has accepted exemplary damages as a legitimate element of private law in Australia. ${ }^{134}$ To be sure, there are jurisdictional issues surrounding awards of exemplary damages in both equity and in tort law. ${ }^{135}$ However, these considerations should not cloud any decision as to whether they should be afforded as a remedy in any new statutory cause of action for invasion of privacy. This decision should look to the merits of exemplary damages, free from any jurisdictional hangover that has seen these damages labelled as inappropriate.

Limiting exemplary damages to strict circumstances, such as those set out in Rookes $v$ Barnard, has been widely criticised ${ }^{136}$ and not accepted in Australia. ${ }^{137}$ There has also been some support for the availability of exemplary damages for certain invasions of privacy. ${ }^{138}$ However, in recommending that a cause of action for privacy be enacted, the ALRC, NSWLRC and VLRC all argued against such a remedy for the causes of action proposed. ${ }^{139}$ Each report assumed that exemplary damages should not

${ }^{131}$ Wilkes $v$ Wood (1763) Lofft 1; 98 ER 489, 498-(Pratt CJ); Uren v John Fairfax (1966) 117 CLR 118, 152 (Windeyer J).

${ }^{132}$ Kuddus v Chief Constable v Leicestershire [2002] 2 AC 122, 154; Fay v Parker 55 NH (1872) 342, 382 quoted in James Edelman, 'In Defence of Exemplary Damages' in Charles E F Rickett (ed), Justifying Private Law Remedies (2008, Hart Publishing), 231.

${ }^{133}$ Rookes v Barnard [1964] AC 1129, 1221 (Lord Devlin); Broome v Cassell \& Co Ltd (No 1) [1972] AC 1027, 1086-7 (Lord Reid). For a discussion of other arguments, such as the suggestion that exemplary damages import an illegitimate element of policy making into the judicial system, see Edelman, 'In Defence of Exemplary Damages' in Rickett (ed), above n $139,225$.

${ }^{134}$ XL Petroleum (NSW) Pty Ltd v Caltex Oil (Aust) Pty Ltd (1985) 155 CLR 448, 472.

135 Broome $v$ Cassell \& Co Ltd (No. 1) [1972] AC 1027, 1086 (Lord Reid), 1114 (Lord Wilberforce); Harris v Digital Pulse Pty Ltd (2003) 56 NSWLR 298, 422 (Heydon JA).

${ }^{136}$ Vorvis $v$ Insurance Corporation of British Columbia [1989] 1 SCR 1085; Fogg v McKnight [1968] NZLR 330; Law Commission UK, Aggravated, Exemplary and Restitutionary Damages Item No 2 of the $6^{\text {th }}$ Programme of Law Reform: Damages (1997) 99-100.

${ }^{137}$ Uren v John Fairfax (1966) 117 CLR 118.

${ }^{138}$ See Law Institute of Victoria, submission No 27 to the Victorian Law Reform Commission, Inquiry into Surveillance in Public Places, June 2010;.Note also, in 1997, the UK Law Commission recommended that punitive damages should be available for a breach of confidence, see Law Commission UK, Aggravated, Exemplary and Restitutionary Damages Item No 2 of the $6^{\text {th }}$ Programme of Law Reform: Damages (1997) 107 [Recommendation 19(a)].

${ }^{139}$ Victorian Law Reform Commission, above n 1, 162-3. 
be available for breaches of privacy based on the argument that the civil law should aim only to restore the plaintiff to the position in which he or she would have been had the wrong not been committed. ${ }^{140}$ The VLRC also stated that 'exemplary damages also raise unresolved concerns, such as whether the criminal law, with its safeguards for defendants, might be the more appropriate forum for punishing a wrongdoer and whether their award may amount to a windfall for the plaintiff. ${ }^{141}$

Australian jurisprudence has increasingly accepted that elements of punishment and deterrence have a historical role, as well as a current role, in civil law. ${ }^{142}$ The High Court has gone as far as questioning the 'sharp cleavage' between civil and criminal law that is said to underpin the inability to award exemplary damages in private law. ${ }^{143}$ Furthermore, courts have accepted that exemplary damages have various legitimate aims. In Lamb v Cotongo the High Court noted that exemplary damages may be awarded to deter, not only the behaviour of the defendant, but also that of 'other likeminded persons' and may apply 'generally to conduct of the same reprehensible kind. ${ }^{, 44}$ The High Court also held that exemplary damages could be legitimately deployed by the court to condemn the action of the defendant, to mitigate any urge for revenge felt by victims and to discourage 'any temptation to engage in self-help likely to endanger the peace.' 145 Finally, the High Court held that damages with punitive aims, even if they could be described as a windfall for the plaintiff, have an 'element of appeasement, if not compensation'. ${ }^{146}$ Despite acceptance of exemplary damages as a legitimate part of Australian law, they are awarded in only the rarest circumstances. ${ }^{147}$ The High Court in Gray $v$ Motor Accident Commission was at pains to emphasise this rarity, stating that exemplary damages 'recognise and punish fault, but not every finding of fault warrants their award. Something more must be found'. ${ }^{148}$

\footnotetext{
${ }^{140}$ Ibid 160; Australian Law Reform Commission, above n 1, vol 3, 2579; New South Wales Law Reform Commission, above n 1, 57.

${ }^{141}$ Victorian Law Reform Commission, above n 1, 160 [7.198].

${ }^{142}$ Uren v John Fairfax (1966) 117 CLR 118, 149-50 (Windeyer J).

143 Gray v Motor Accidents Commission (1998) 196 CLR 1, 7-8 (Gleeson CJ, McHugh, Gummow and Hayne JJ).

144 (1987) 164 CLR 1, 10 (Mason CJ, Brennan, Deane, Dawson and Gaudron JJ).

${ }^{145}$ Ibid 9.

${ }^{146}$ Ibid 10.

147 Gray v Motor Accident Commission (1998) 196 CLR 1, 5-9 (Gleeson CJ, McHugh, Gummow and Hayne JJ).

${ }^{148}$ Ibid 6.
} 
The European Court of Human Rights has acknowledged that large monetary orders in privacy matters can have a deterrent impact. ${ }^{149}$ In Mosley $v$ News Group Newspapers Limited, ${ }^{150}$ the defendant was ordered to pay $£ 60000$ in damages, ${ }^{151}$ along with a costs order of approximately $£ 420000$, in addition to his own legal fees. ${ }^{152}$ The European Court of Human Rights noted that the order, although not labelled exemplary or punitive, could 'reasonably be expected to have a salutary effect on journalistic practices'. ${ }^{153}$

One situation where exemplary damages should be awarded is where publication of private material has occurred in a manner which indicates that the publisher has chosen to inflame or heighten the invasion of privacy. Here, a court would assess whether the way in which the privacy has been breached, or the medium chosen to publish private information, has increased the impact that the breach of privacy has had on the plaintiff. There is already judicial support in the United Kingdom and Europe for a multi-layered understanding of privacy, whereby the facts constituting the intrusion of privacy are considered to establish not only the breach but also the quantum of damages. ${ }^{154}$ For example, in Mosley $v$ United Kingdom, the court held that the publication of videos and photographs of the plaintiff's sexual engagement with prostitutes, on top of a textual account of the matter, was a deep intrusion into the plaintiff's privacy which only served to 'titillate and entertain'. ${ }^{155} \mathrm{An}$ award of damages could include an expressly punitive element directed at media outlets which choose to go above and beyond what is required to tell a story adequately and where that choice has seriously increased the invasion of privacy. The media would be free to take the risk of breaching a person's privacy in telling a story, but would do so knowing they would be particularly punished if they did so in a way which unnecessarily humiliated or disgraced the person.

The express availability of deterrence as an aim of redress in breaches of personal privacy could also prove important in situations involving new media and technologies. For example, a person such as Giggs, who has successfully

\footnotetext{
${ }^{149}$ Note that the European Court of Human Rights does not award exemplary damages: see $B B$ $v$ United Kingdom (European Court of Human Rights, Fourth Section Chamber, Application No 53760/00, 7 July 2004) [36].

${ }^{150}$ [2008] EWHC 1777 (QB) (24 July 2008).

${ }^{151}$ Ibid [236].

${ }^{152}$ Mosley v United Kingdom [2011] Eur Court HR 774 [28], [119].

${ }^{153}$ Ibid [119].

${ }^{154}$ Douglas $v$ Hello! Ltd (No 3) [2006] QB 125, 157 [84]; Von Hannover v Germany (2005) 40 EHRR 1; Cf Campbell [2003] QB 633, [64] (Lord Phillips).

155 [2011] Eur Court HR 774 [114].
} 
gained an injunction for an apprehended breach of personal privacy, may later bring an action against a person who breaches both their privacy and the injunction by posting on a social media website such as Twitter. ${ }^{156}$ In this case, an element of exemplary damages, proportionate to the circumstances and appropriate to the party who has breached the privacy, should be considered, especially if the offending party obtained and published the information in the knowledge of the injunction and in flagrant disregard of the rights of the plaintiff. The courts would be able to send a message to internet users that privacy and court ordered injunctions should not be lightly and flagrantly breached.

Other jurisdictions have acknowledged the role that punitive awards can play in redressing breaches of personal privacy. In Herrity $v$ Associated Newspapers [Ireland] Ltd, ${ }^{157}$ the plaintiff sued a newspaper for publishing private information about a sexual relationship between the plaintiff and a priest. In addition to $€ 60000$ in compensatory and aggravated damages, the High Court of Ireland awarded the plaintiff $€ 30000$ in punitive damages, for the 'flagrant and unwarranted breach' of the plaintiff's privacy.

Courts in Canada have awarded punitive damages for breaches of statutory causes of action for privacy, which have been enacted in British Columbia, Manitoba, Newfoundland and Labrador, Saskatchewan and the civil law province of Quebec. ${ }^{158}$ In 2008, Truscott J of the Supreme Court of British Columbia upheld an award $\$ 35000$ in punitive damages for an invasion of privacy, where the plaintiff, who had been in a sexual relationship with the defendant, was secretly filmed while in the defendant's bathroom. ${ }^{159}$ The plaintiff and her child had been filmed via a peephole set up by the defendant in the bathroom cabinet, where the filming had been assisted by the specific arrangement of mirrors. ${ }^{160}$ The court accepted that, as a result of these events, the plaintiff had been humiliated, had struggled to enter intimate relations for fear of being tapped again and had been unable to work for about one year due to ongoing depression. ${ }^{161}$ The plaintiff had been prescribed

\footnotetext{
${ }^{156}$ Another issue that is likely to coincide with increased use of social media and corresponding privacy breaches is the question of rights to anonymity. The issue of anonymity of bloggers was considered by Eady $\mathrm{J}$ in The Author of a Blog $v$ Times Newspapers [2009] EWHC 1358 (QB) (16 June 2009).

${ }^{157}$ [2008] IEHC 249.

${ }^{158}$ Privacy Act, RSBC 1996, c 373; Privacy Act, RSM 1987, c P125; Privacy Act, RSS 1978, c P-24; Privacy Act, RSNL 1990, c P-22; Civil Code of Quebec, RSQ 1991, c 64, a 35.

${ }^{159}$ L.A.M. v. J.E.L.I. [2008] British Columbia Supreme Court 1147 [42].

${ }^{160}$ Ibid [2]

${ }^{161}$ Ibid [19]-[20], [24].
} 
antidepressants and had also seen a counsellor. ${ }^{162}$ Truscott $\mathrm{J}$ explicitly stated that the plaintiff was seeking to punish the defendant for his action and that civil action was the only legal recourse open to her, due to the operation of the criminal law at the time of the offence. ${ }^{163}$ The award of punitive damages was additional to compensatory damages and a nominal amount that had been awarded for loss of capacity to earn income. ${ }^{164}$

In Malcolm v Fleming, ${ }^{165}$ another Canadian case relating to secret videotaping of a woman in a bathroom, Downs J awarded punitive damages of $\$ 35000$, in part to acknowledge the 'ongoing nature of that invasion and the possibility of it being disseminated to other persons ${ }^{166}$ flowing from the fact that privacy had not just been invaded, but captured on video tape.

A non-exhaustive list of considerations that a court could take into account when awarding exemplary damages - a list drawing on case law and existing statutory regimes providing for exemplary damages ${ }^{167}$ — would ensure consistency in the making of such awards. The list of factors that could be considered by the courts should include:

1. whether the defendant acted intentionally in disregard, or consciously in contumelious disregard, of the rights of the plaintiff or persons in the position of the plaintiff;

2. whether the conduct subject to the claim had already given rise to criminal punishment and, if so, the extent of that punishment;

3. the extent to which the conduct subject to the claim was inconspicuous, secretive or hidden;

4. the extent, thoroughness and duration of the privacy breach;

5. the need to deter similar breaches of personal privacy;

\footnotetext{
${ }^{162}$ Ibid [21]

163 Ibid [17], [23]

${ }^{164}$ Ibid [38]-[39].

165 [2000] Carswell British Columbia Cases 1316 (British Columbia Supreme Court).

${ }^{166}$ Ibid [21].

${ }^{167}$ See, eg, Copyright Act 1968 (Cth) s 115(4); Gray v Motor Accident Commission (1998) 196 CLR 1, 8-15 (Gleeson CJ, McHugh, Gummow and Hayne JJ), 33-4 (Kirby J).
} 
6. the conduct of the defendant during the act and after the invasion of personal privacy, or after the plaintiff realised that his or her privacy had been breached;

7. any benefit which the defendant gained through the breach of personal privacy; and

8. any other relevant matters.

The media and other stakeholders fear that enacting a statutory cause of action may lead to the chilling of freedom of speech. ${ }^{168}$ This fear would be compounded if exemplary damages were made available. However, other jurisdictions that have causes of action for privacy, be they statutory or at common law, have not seen a flurry of cases in privacy before the courts. Instead, journalists and the general public learn what is acceptable and what is not, which then moulds their behaviour. ${ }^{169}$ The availability of exemplary damages can play an important part in this moulding process, enabling the court to condemn the most egregious breaches of personal privacy. Furthermore, as discussed, the experience in Canada in relation to privacy cases and Australia in other areas of the law, is that courts are wise enough to award exemplary damages with restraint. ${ }^{170}$

Another argument raised against the availability of exemplary damages in cases of personal privacy is that legislative reform in other areas has deliberately restricted the award of these damages. ${ }^{171}$ For example, Australian uniform defamation laws bar exemplary damages, ${ }^{172}$ overturning the common

\footnotetext{
${ }^{168}$ Australian Law Reform Commission, above n 1, vol 3, 2558-60.

${ }^{169}$ Mr Justice Eady (Speech delivered at the University of Hertfordshire, 10 November 2009), 16 available at <http://www.judiciary.gov.uk/Resources/JCO/Documents/Speeches/justiceeady-univ-of-hertfordshire-101109.pdf ''; Simon Chester, Jason Murphy and Eric Robb, 'Zapping the Paparazzi: Is the Tort of Privacy Alive and Well?' (2003) 27 Advocates' Quarterly 357, 364.

${ }^{170}$ Gray v Motor Accidents Commission (1998) 196 CLR 1, 6 (Gleeson CJ, McHugh, Gummow and Hayne JJ); Simon Chester, Jason Murphy and Eric Robb, 'Zapping the Paparazzi: Is the Tort of Privacy Alive and Well?' (2003) 27 Advocates' Quarterly 357, 364-5; Penelope Watson, 'Remedies for Novel Torts: Invasion of Privacy' (2008) 1 Journal of the Australasian Law Teachers Association 391, 400.

${ }^{171}$ For a discussion of the tendency of the parliament to restrict exemplary damages see Harris v Digital Pulse Pty Ltd (2003) 56 NSWLR 298, 362-3 (Heydon JA).

172 Defamation Act 2005 (Vic) s 37; Defamation Act 2005 (NSW) s 37; Defamation Act 2005 (WA) s 37; Defamation Act 2005 (SA) s 35; Defamation Act 2005 (QLD) s 37; Defamation Act 2005 (Tas) s 37.
} 
law acceptance of the remedy. ${ }^{173}$ Despite this trend, some statutes provide for exemplary damages. ${ }^{174}$

It is right to question why a defamed plaintiff should not be afforded a right to exemplary damages but a plaintiff whose privacy has been breached should. With regard to defamation, a compensatory monetary award and official recognition of the wrong may be enough to ameliorate the harm done to the defamed person, as a successful defamation case may vindicate the plaintiff, uphold their reputation and compensate them for the emotional hurt suffered via the defamatory imputations. ${ }^{175}$ However, as is often said, lost privacy cannot so easily be corrected or compensated. With compensation for hurt to feelings being harder to achieve in privacy cases, there is a corresponding need to deter actions leading to a breach of this right, or at least to deter breaches undertaken in offensive disregard of this right.

There are also practical steps that could be taken to safeguard against unintended use of the remedy by the courts and to allay the fears of the media. In addition to capping the total amount of damages for non-economic loss, the availability of exemplary damages could also be balanced by the operation of 'defences' to the award of this remedy. For example, in Fontin v Katapodis the High Court accepted that provocation may operate to vitiate or reduce an amount awarded as exemplary damages. ${ }^{176}$

Obviously exemplary damages will not deter all future invasions of personal privacy. However, the availability and sparing use of exemplary damages will strike the balance between deterrence from brutal invasions of privacy and personal liberty from heavy-handed civil remedies. ${ }^{177}$

\section{Account of Profits}

There are likely to be difficulties in awarding an account of profits in privacy claims, as there are with breaches of confidence. Firstly, many privacy breaches, such as in the peephole example, will not give rise to any profit in the hands of the defendant. Secondly, where privacy has been breached and a

\footnotetext{
${ }^{173}$ See, eg, Uren v John Fairfax (1966) 117 CLR 118.

${ }^{174}$ Copyright Act 1968 (Cth) s 115(4); Water Act 2000 (QLD) s 788(2)(b).

${ }^{175}$ Carson v John Fairfax \& Sons Ltd (1993) 178 CLR 44, 60-1 (Mason CJ, Deane, Dawson and Gaudron JJ), 71 (Brennan J); McCarey v Associated Newspapers Ltd (No 2) [1965] 2 QB 86, 104; Uren v John Fairfax (1966) 117 CLR 118, 150 (Windeyer J).

176 (1962) 109 CLR 177, 187; Lamb v Cotogno (1987) 164 CLR 1, 13 (Mason CJ, Brennan, Deane, Dawson and Gaudron JJ).

${ }^{177}$ See Edelman, 'In Defence of Exemplary Damages' in Rickett (ed), above n 139, 247-8.
} 
profit has been made - for example where a newspaper publishes information in breach of privacy and the story is successful with readers - it is difficult to determine the amount of profit that the privacy breach has directly caused. However, as was noted by the ALRC and NSWLRC, difficulty in determining the profit should not be a reason for that remedy's non-existence. ${ }^{178}$ Therefore, despite being a remedy that may only be awarded in exceptional circumstances, an account of profits should nevertheless be available to the courts.

\section{Non-exhaustive List of Remedies}

Unlike the ALRC report, the NSWLRC report included a catch-all remedy enabling the courts to order 'other remedies or orders that the court thinks appropriate in the circumstances'. ${ }^{179}$ The NSWLRC argued that having more flexible remedies "enables the court to draw on analogous common law and statutory law to fashion relief that is appropriate to the circumstances of the particular case'. ${ }^{180}$ The report went on to suggest that remedies under a general clause such as this could include asset preservation orders and search orders. ${ }^{181}$

A non-exhaustive list of remedies would allow the courts to impose remedies for situations not yet conceived of by the legislative drafters. With the rise of social media, breaching privacy has become much easier, faster and potentially more damaging. ${ }^{182}$ It is increasingly possible for ordinary people, who, unlike the mainstream media, do not have large sums of money to pay damages and costs orders, to cause wide-scale privacy breaches. For this reason, remedial creativity may be beneficial in the future.

In 2011 it was reported that Fahmi Fadzil came to an agreement with a Malaysian magazine to 'tweet' 100 apologies after he posted allegedly defamatory remarks on his Twitter account about the Human Resources department of that magazine. ${ }^{183}$ It should be left open to the courts in privacy

\footnotetext{
${ }^{178}$ New South Wales Law Reform Commission, above n 1, 66.

${ }^{179}$ Ibid 57.

${ }^{180}$ Ibid 58.

181 Ibid.

182 Althaf Marsoof, 'Online Social Networking and the Right to Privacy: The Conflicting Rights of Privacy and Expression' (2011) 19(2) International Journal of Law and Information Technology 110.

${ }^{183}$ Chris Gayomali, Malaysian Man Tweets 100 Apologies to Avoid Lawsuit (2 June 2011) Time Techland <http://techland.time.com/2011/06/02/malaysian-man-tweets-100-apologiesto-avoid-lawsuit/>
} 
cases to impose orders for such apologies, corrections and other action online. Giving the courts the flexibility to deal in the best way possible with types of privacy breaches which we cannot contemplate now will ensure that any legal reform in the area of personal privacy will stand the test of time. However, in order to ensure that remedies are not haphazardly awarded at the whim of the court, legislation should mandate that any remedy which is not explicitly provided for by the legislation can be awarded only where all other remedies are unavailable or inappropriate - with the plaintiff bearing the onus of establishing this.

\section{E Pre-notification Requirements}

Another remedy that has been suggested in privacy matters is a prenotification requirement. After being awarded $£ 60000$ plus costs, Max Mosley appealed his case to the European Court of Human Rights, arguing that ECHR article 8 requires a publisher to pre-notify the subject of a publication which is about to disclose material related to his or her private life. ${ }^{184}$ The application centred on the notion that the availability of injunctive relief is futile where the potential breach of personal privacy has been kept secret from an aggrieved person. After assessing various privacy laws and protections under the law in the United Kingdom, the European Court dismissed Mosley's claim on grounds which included the findings that:

a) A pre-notification requirement would need a 'public interest' exception, affording a publisher the choice not to pre-notify a potential claimant. This exception could not be defined too narrowly, or it would fall foul of $E C H R$ art 10 . Therefore, it is not unlikely that News of the World would have chosen not to notify Mosley of the pending publication.

b) Only the threat of a punitively high fine would be likely to deter newspapers from publishing private material without pre-notification; and, even then, a publisher could run the risk of publication in the knowledge that a fine would be incurred after the fact. ${ }^{185}$

The pre-notification suggestion by Mosley is flawed on policy grounds in that it would require the media to consistently inform people of the chance that their privacy would be breached. This would fundamentally increase the time and cost of journalism. Furthermore, whilst exemplary damages would be

\footnotetext{
${ }^{184}$ Mosley v United Kingdom [2011] Eur Court HR 774.

${ }^{185}$ Ibid [125]-[128].
} 
awarded only in the rarest cases of outrageous conduct, it would be incumbent on a court to punish a party which had not complied with the requirement for pre-notification, even if the initial breach of privacy was not particularly intrusive. Finally, the imposition of a pre-notification requirement would be unworkable in the modern world, where publication of private facts is increasingly likely to be undertaken by the public rather than the mainstream media. It is impossible to expect that the public, such as bloggers and Twitter users, would comply with pre-notification requirements. Thus, the media would be disadvantaged in their pursuit of breaking news when compared with citizen journalists.

\section{CONCLUSION}

American jurist Charles Fried once wrote that 'privacy is not simply an absence of information about us in the minds of others; rather it is the control we have over information about ourselves'. ${ }^{186}$ However, as Fried went on to say, one must acknowledge the 'inevitable fact that privacy is gravely compromised in any concrete social system' due to the 'utterly just exercise of rights by others'. ${ }^{187}$ While we may have to accept that our privacy will be compromised in a modern society, if we choose to legislate to curb the increased intrusion into our private lives, we need to make available to the courts the most appropriate remedial options. This includes allowing the courts to actively deter particularly heinous actions in disregard of the right to privacy. Rapid advances in technology mean that we cannot predict the ways in which our privacy will be challenged in the years to come. This adds further weight to the argument that the judiciary should be afforded a flexible and practical array of remedies to make good intrusions into personal privacy. Central to this notion of remedial flexibility, are exemplary damages, which should be available to be awarded in the rarest circumstances, to punish the defendant, deter his or her peers and show the court's condemnation of breaches of personal privacy conducted with the utmost disregard for another's rights.

\footnotetext{
${ }^{186}$ Charles Fried, 'Privacy' (1968) 77 Yale Law Journal 475, 482.

${ }^{187}$ Ibid 487.
} 